\title{
Relative efficiency of alternative methods to evaluate wood stiffness in the frame of hybrid larch (Larix $\times$ eurolepis Henry) clonal selection
}

\author{
Dominique JACQUES*, Michèle MARCHAL, Yannick CURNEL
}

Centre de Recherche de la Nature, des Forêts et du Bois, Ministère de la Région Wallonne, DGRNE, avenue Maréchal Juin, 23, 5030 Gembloux, Belgium

(Received 22 February 2002; accepted 19 December 2002)

\begin{abstract}
This study compares the efficiency of 3 indirect techniques that evaluate Young's modulus all along the sawing leading to the production of normalised specimens of hybrid larch trees from a clonal test. Ultrasonic speed is demonstrated as an interesting method for clone classification regarding Young's modulus in a clonal selection programme, whatever the sawing stage. However, the quality of results is reduced with standing tree measurements. The use of both the Pilodyn and resonance frequency measures is confirmed as a possibility.
\end{abstract}

Young's modulus / ultrasound / resonance frequency / Pilodyn / Larix $\times$ eurolepis

Résumé - Efficacité relative de méthodes alternatives d'évaluation de la rigidité du bois de mélèze hybride (Larix $\times$ eurolepis Henry) dans le cadre d'une sélection clonale. L'efficacité relative de 3 techniques d'évaluation du module d'élasticité par voie indirecte a été testée sur différents types d'échantillons au cours des étapes de la découpe de mélèzes hybrides, issus d'un test clonal, depuis l'arbre debout jusqu'aux éprouvettes normalisées selon la norme NF B 51-016. Cette étude fait apparaitre que la mesure de la vitesse ultrasonore s'avère une méthode satisfaisante de classement des clones pour le module d'élasticité dans le cadre d'un programme de sélection clonale, quel que soit le type d'échantillon utilisé. La qualité des résultats se réduit cependant avec l'augmentation de la taille des échantillons pour devenir minimale lorsque la mesure est réalisée sur arbre debout. Les résultats positifs des mesures à l'aide du Pilodyn, effectuées sur arbre debout, ainsi que les mesures de la fréquence de résonance, réalisées sur éprouvettes normalisées et barreaux, confirment et justifient l'intérêt qui leur est porté par de nombreux auteurs.

module d'élasticité / ultrason / fréquence de résonance / Pilodyn / Larix $\times$ eurolepis

\section{INTRODUCTION}

In the frame of a genetic improvement programme, technological characteristics such as wood stiffness could be considered as selection criteria, in the same way as growth or form, to maintain or slightly improve the mechanical properties of wood produced.

Wood stiffness is generally evaluated by the determination of the modulus of elasticity in static bending performed on normalised specimens submitted to a reference test [1]. However this method is expensive, time-consuming and requires a particular conditioning of the material (sawing, the choice of clear $\operatorname{wood} . .$.$) .$

For several years, many researchers have tried to develop different techniques to reduce the duration and the cost of these types of wood analyses, in laboratory or ideally on standing trees, by using indirect measures. Basic density measured on increment core [8] is certainly the most common technique but others can also be carried out, such as the Torsiometer
[10], used previously, or the Pilodyn measures which provide better estimation $[7,9,10]$.

Another technique is the direct evaluation of the modulus of elasticity (MOE) on standing trees. Trials to experimentally determine this value on standing trees have already been set up. Vafai and Farshad [33] developed a machine to measure the MOE of wood in standing trees and the French Institute INRA recently developed and tested a new device, derived from the one elaborated and used by Koizumi et al. [17-19], for rapid measurement of the trunk equivalent modulus: the Modulometer more recently called Rigidimeter [20, 21, 26]. In comparison to the traditional bending test carried out in the laboratory, this machine provides a rapid evaluation of the MOE and allows the ranking of trees in a similar way. However, its use requires specific tree dimensions $[20,21]$ and climatic conditions (Pâques L., pers. com.).

For hybrid larch which is a very promising species in term of growth potential and more specifically in the frame of clonal selection [14], we will compare the relative efficiency

* Corresponding author: d.jacques@mrw.wallonie.be 
of 3 indirect measures of the modulus of elasticity at the different steps leading to the production of normalised specimens, by means of the Sylvatest ${ }^{1}$, Grindo-Sonic ${ }^{2}$ and Pilodyn. The final objective of this study is to ascertain the easiest method of ranking hybrid larch clones according to their wood stiffness.

\section{MATERIALS AND METHODS}

\subsection{Testing methods}

The first three testing methods have been previously described and illustrated [27].

\subsubsection{Control method}

The method measures modulus of elasticity in static bending $\left(\mathrm{MOE}_{4 \mathrm{PT}}\right)$ as described in the French standard NF B 51-016 [1, 27], by means of an "Instron 5582" engine. It is used as the control method. In this way, a global evaluation of a tree is determined by the measurements of 12 samples collected in the first 6 metres of the trunk.

Three other methods are compared with this control.

\subsubsection{Ultrasound method by means of the Sylvatest}

The Sylvatest device allows for the measurement of ultrasound wave propagation time (emission frequency $50 \mathrm{kHz}$ ) in the longitudinal direction of the specimen [27].

Ultrasound propagation speed in wood $\left(\mathrm{V}_{\mathrm{US}}\right.$ in $\left.\mathrm{m} \mathrm{s}^{-1}\right)$ is the ratio between sample length and measured time. It is used to estimate the modulus of elasticity according to the following equation:

$$
\mathrm{MOE}_{\mathrm{US}}=\mathrm{V}^{2} \mathrm{US} \rho 10^{-6}[4,5,13,31]
$$

where $\mathrm{V}_{\mathrm{US}}$ is the ultrasound propagation speed in the longitudinal direction, in metres per second $\left(\mathrm{m} \mathrm{s}^{-1}\right), \rho$ is the wood density [27], in kilograms per cubic metre $\left(\mathrm{kg} \mathrm{m}^{-3}\right)$ and $\mathrm{MOE}_{\mathrm{US}}$, the modulus of elasticity in longitudinal direction, in megapascals $(\mathrm{MPa})$.

In addition, ultrasonic speed $\left(\mathrm{V}_{\mathrm{US}}\right)$ measured on different kinds of samples is also used to rank the clones. This ranking is compared to the results obtained by the modulus of elasticity in static bending (control).

\subsubsection{Resonance frequency method by means of the Grindo-Sonic}

The Grindo-Sonic measures Young's modulus by analysing the natural period of the transient vibration which results from a mechanical disturbance of the object tested [27].

These vibratory phenomena are complex and depend on the nature of the matter, the impact force and the physical characteristics of the piece put in vibration $[6,11]$. The absorption of vibrations, variable from one matter to another, can consequently be a characteristic of the matter tested.

The Grindo-Sonic device transforms the incoming signal received from this natural frequency in an electric current of the same frequency and relative amplitude, during eight periods, due to a quartz clock where the reference crystal oscillates at $2 \mathrm{MHz}$ [24]. The read-

${ }^{1}$ Elaborated by JL Sandoz, École Polytechnique Fédérale de Lausanne, IBOIS Construction en bois; GCH2 Ecublens, CH-1015 Lausanne, Suisse.

2 Elaborated by JH Lemmens, Dynamic Materials Testing Instruments; Geldenaaksebaan, 456, B-3001 Leuven, Belgium - Model MK3S. ing $R$ corresponds to the duration of two specific periods and is expressed in microseconds. The specific frequency $\left(\mathrm{F}_{\mathrm{r}}\right.$ in $\left.\mathrm{Hz}\right)$ is given by:

$$
\mathrm{F}_{\mathrm{r}}=\frac{2 \times 10^{6}}{R}[24,27] \text {. }
$$

The characteristic dynamic modulus $\left(\mathrm{MOE}_{\mathrm{GR}}\right.$ in $\mathrm{MPa}$ ) is given by the transformed Spinner and Tefft equation applied to samples with transversal rectangular section:

$$
\mathrm{MOE}_{\mathrm{GR}}=3.78568 \frac{\mathrm{ML}^{3}}{\mathrm{bh}^{3} R^{2}} 10^{6}[27,32],
$$

where $\mathrm{M}$ is the mass in grams $(\mathrm{g})$ and $\mathrm{L}, \mathrm{b}$ and $\mathrm{h}$ are respectively the length, width and thickness in millimetres $(\mathrm{mm})$.

A shock was applied perpendicularly to the sample length and tangentially to the rings, the probe being in a radial position [27].

\subsubsection{Pilodyn}

The Pilodyn, originally developed in Switzerland [10], measures the penetration depth into a wood material of a calibrated low diameter striker pin propelled by a fixed energy, generally 6 joules.

The more tender the wood, the more important the penetration depth. There is, consequently, a negative relationship between penetration depth and wood density $[7,8,10]$.

The relationship between the Pilodyn measurement and modulus of elasticity does not seem to be documented. However, as the Pilodyn measurement and density are well correlated for hybrid larch [22], it is pertinent to evaluate the intensity of this relationship and its efficiency in view of clonal selection.

\subsection{Experimental material and measures}

A set of 16 hybrid larch (Larix $\times$ eurolepis Henry) clones was selected in a clonal test established in Virton (Walloon Region, Southern Belgium) in 1982.

Thirty-two trees consisting of 2 ramets $^{3}$ per clone were selected from the dominant trees, and measured at the forest stage. Ultrasound speed $\left(\mathrm{V}_{\mathrm{US}}\right)$ was recorded between 0.5 and $2.0 \mathrm{~m}$ on the North face of each tree, in the sapwood. Two over bark measures with the Pilodyn were also recorded on standing trees at $1.3 \mathrm{~m}$ on the North and South faces in 1993 and on the Southeast and Northwest faces in 1996, to avoid compression wood being normally maximum in the Northeast part of the trunk (the dominant winds blow from the Southwest in Belgium).

These 14-year-old trees were felled in the winter of 1995-1996 and each basal trunk sawn into $3 \operatorname{logs}$ from 1.5 to $2.5 \mathrm{~m}$ in length, before being transported to the laboratory.

At the various sampling stages, different measurements were carried out (Tab. I).

For each log, ultrasound speed was measured between the 2 opposite radial faces of the same ring, in the same orientation (North and South): 2 measurements were carried out in the heartwood, and 2 in the sapwood.

The next step was the sawing of each $\log$ into 4 boards, $3 \mathrm{~cm}$ thick, in the N-E, S-E, S-W and N-W directions. At this stage, a third group of ultrasound speed measurements $\left(\mathrm{V}_{\mathrm{US}}\right)$ was conducted producing one data per board.

This was followed by the cutting in the sapwood of each board of a long specimen (from 362 to $712 \mathrm{~mm}$ long with a cross section of $20 \times 20 \mathrm{~mm}$ ) containing the ring chosen for the ultrasound speed measurement. The dimensions, density, ultrasound speed $\left(\mathrm{V}_{\mathrm{US}}\right)$ and resonance frequency $(\mathrm{Fr})$ were measured, each one providing one

\footnotetext{
${ }^{3}$ Vegetative copy of a plant derived initially from a seedling.
} 
Table I. List of the measurements realised on the experimental material and number of data used for statistical analysis.

\begin{tabular}{lcc}
\hline Material & Measurement & Data number \\
\hline Standing tree & $\begin{array}{c}\text { Pilodyn pin penetration in 1993, } \\
\text { Pilodyn pin penetration in 1996, }\end{array}$ & 32 \\
& ultrasound speed & 32 \\
Felled tree & & 32 \\
3 logs per tree & Ultrasound speed & \\
4 boards per log & Ultrasound speed & 36 \\
1 long specimen & Density, & 384 \\
per board & ultrasound speed and modulus, & 384 \\
& resonance frequency and modulus & 384 \\
1 clear specimen & Density, & 384 \\
per long specimen & ultrasound speed and modulus, & 384 \\
& resonance frequency and modulus, & 384 \\
& modulus of elasticity in static bending & 384 \\
\hline
\end{tabular}

value per specimen, and the two alternative moduli of elasticity were calculated ( $\mathrm{MOE}_{\mathrm{US}}$ and $\mathrm{MOE}_{\mathrm{GR}}$ ).

Finally, normalised clear specimens $(20 \times 20 \times 360 \mathrm{~mm})$ were sawn, one by long specimen, to record the modulus of elasticity by means of the three non-destructive testing (NDT) ${ }^{4}$ : the four points static bending method $\left(\mathrm{MOE}_{4 \mathrm{PT}}\right)$, the resonance frequency and ultrasound methods (respectively $\mathrm{MOE}_{\mathrm{GR}}$ through $\mathrm{Fr}$ and dimensions, and $\mathrm{MOE}_{\mathrm{US}}$ through $\mathrm{V}_{\mathrm{US}}$ and density), each data corresponding to the mean of three successive measurements. In the case of the ultrasound method, with samples of $360 \mathrm{~mm}$ long, we were under the $500 \mathrm{~mm}$ instruction length required for our type of Sylvatest, which could slightly affect the results.

All characteristics were measured at $12 \%$ moisture content. For wood pieces not originally at this moisture content (boards, logs), ultrasound speed was corrected according to Sandoz [31].

\subsection{Statistical analysis}

The mean by ramet at each stage of sampling was submitted to a variance and a covariance analysis [30] according to the following linear model:

$$
X_{i j}=\mu+C_{i}+\varepsilon_{i j}[30]
$$

where $\mu$ is the general mean, $C_{i}$, the effect of clone $i$ and $\varepsilon_{i j}$, the residuals.

From the general variance/covariance analyses [30], it is possible to derive the conventional direct gain $\left(\Delta \mathrm{G}_{\mathrm{C}}\right.$ in $\left.\%\right)$ calculated as:

$$
\Delta \mathrm{G}_{\mathrm{C}}=\mathrm{i} \mathrm{h}{ }^{2}{ }_{\mathrm{G}} \mathrm{CV}_{\mathrm{P}}[28-30]
$$

in which $\mathrm{i}$ is the selection differential (fixed here, as 1 ), $\mathrm{h}^{2} \mathrm{G}$ is the genotypic heritability on the means per clone and $\mathrm{CV}_{\mathrm{P}}$, the phenotypic coefficient of variation on the means per clone expressed in per cent.

The parameters obtained from the reference method will be compared with the indirect genotypic gain calculated as:

$$
\Delta \mathrm{G}_{\mathrm{Y} / \mathrm{X}}=\mathrm{i}_{\mathrm{X}} \mathrm{h}_{\mathrm{GX}} \mathrm{h}_{\mathrm{Gy}} \mathrm{r}_{\mathrm{G}} \mathrm{CV}_{\mathrm{Py}}[28,30]
$$

which corresponds to the gain realised by clonal selection on a character (Y) by selection on another character (X). In our case, $\mathrm{Y}$ is the control method and $\mathrm{X}$ the alternative ones.

\footnotetext{
${ }^{4}$ NDT refers to the methods, not to the sampling.
}

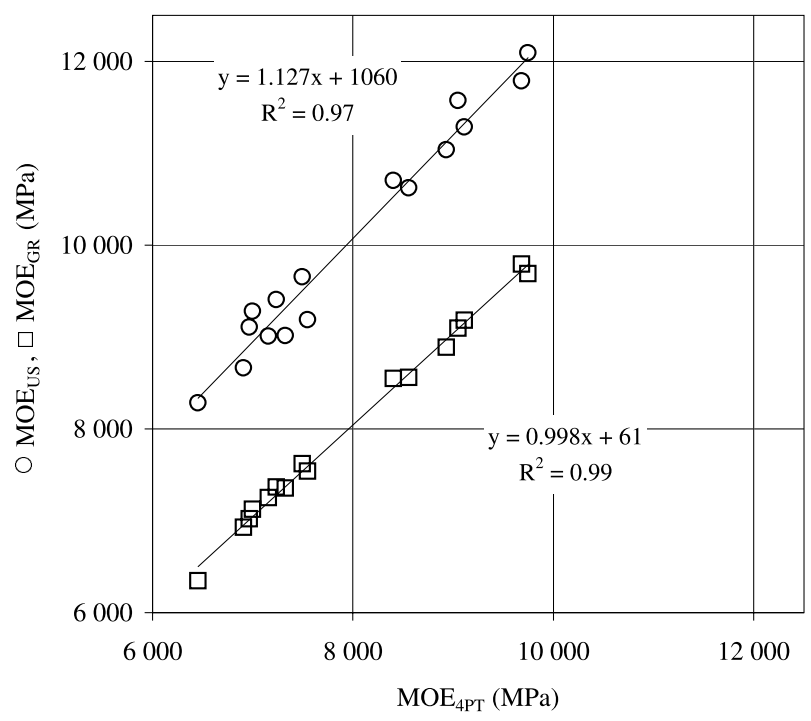

Figure 1. Regression straight line between modulus of elasticity in static bending (control method - $\mathrm{MOE}_{4 \mathrm{PT}}$ ) and moduli estimated by the ultrasound (MOEUS) and the frequency resonance methods (MOEGR) on normalised specimens for 16 clones.

This formula shows that the best results are obtained with an alternative method which is highly heritable and genotypically correlated with the control method.

Finally, to compare the means of modulus of elasticity measured by the different methods, the test of the difference of two means of non independent samples is also performed [12].

\section{RESULTS AND DISCUSSION}

\subsection{Estimation of the genotypic parameters}

\subsubsection{Normalised specimens}

Modulus of elasticity predicted by the ultrasound method was, in average, over-evaluated (Fig. 1 and Tab. II) by $25 \%$ as compared with the control method. This tendency to overevaluate the modulus of elasticity using ultrasound method is confirmed by other authors $[2,15,16,27]$.

On the other hand, the control and the frequency methods produce similar results, the two means being statistically equal [12].

Estimates of genotypic heritability for the modulus of elasticity are very high, regardless of the method used, and do not vary much, from 0.74 to 0.80 .

Estimates of direct gain are also similar and quite high, slightly lower for the modulus obtained by ultrasound method, varying between 10.9 and $11.8 \%$.

Estimates of genotypic heritability for ultrasound speed (0.60) and resonance frequency (0.64) are lower than those calculated for the respective moduli.

\subsubsection{Long specimens}

Estimates of genotypic heritability and direct gain for the modulus of elasticity measured on long specimens appear 
Table II. Normalised specimens: mean, maximum $(\max )$ and minimum $(\min )$ of the ultrasound speed $\left(\mathrm{V}_{\mathrm{US}}, \mathrm{m} \mathrm{s}^{-1}\right)$ and modulus $\left(\mathrm{MOE}_{\mathrm{US}}, \mathrm{MPa}\right)$, the resonance frequency $(\mathrm{Fr}, \mathrm{Hz})$ and modulus $\left(\mathrm{MOE}_{\mathrm{GR}}, \mathrm{MPa}\right)$, the modulus of elasticity in static bending $(\mathrm{MOE} 4 \mathrm{PT}, \mathrm{MPa})$; different genotypic parameters as heritability $\left(\mathrm{h}^{2} \mathrm{Gi}\right)$ with confidence limits ${ }^{5}$, phenotypic coefficient of variation $\left(\mathrm{CV}_{\mathrm{P}} \%\right)$ and direct genotypic gain $\left(\Delta \mathrm{G}_{\mathrm{C}}, \%\right)$ at clonal level $(n=16)$.

\begin{tabular}{lcccccc}
\hline Method & Mean & Max & Min & $\mathrm{h}^{2} \mathrm{Gi}$ & $\mathrm{CV}_{\mathrm{P}}$ & $\Delta \mathrm{G}_{\mathrm{C}}$ \\
\hline $\mathrm{V}_{\mathrm{US}}\left(\mathrm{m} \mathrm{s}^{-1}\right)$ & 4900 & 5200 & 4500 & $0.60(0.18-0.84)$ & 4.2 & 3.2 \\
MOE $_{\mathrm{US}}(\mathrm{MPa})$ & 10000 & 12100 & 8300 & $0.80(0.52-0.92)$ & 12.3 & 10.9 \\
$\mathrm{Fr}(\mathrm{Hz})$ & 692 & 742 & 619 & $0.64(0.23-0.85)$ & 5.1 & 3.9 \\
MOE $_{\mathrm{GR}}(\mathrm{MPa})$ & 8000 & 9800 & 6300 & $0.79(0.49-0.92)$ & 13.4 & 11.8 \\
MOE $_{4 \mathrm{PT}}(\mathrm{MPa})$ & 8000 & 9700 & 6500 & $0.74(0.41-0.90)$ & 13.5 \\
\hline
\end{tabular}

Table III. Long specimens: mean, maximum (max) and minimum (min) of the ultrasound speed $\left(\mathrm{V}_{\mathrm{US}}, \mathrm{m} \mathrm{s}^{-1}\right)$ and modulus (MOE $\mathrm{US}_{\mathrm{S}}$, MPa), the resonance frequency $(\mathrm{Fr}, \mathrm{Hz})$ and modulus $\left(\mathrm{MOE}_{\mathrm{GR}}, \mathrm{MPa}\right)$; different genotypic parameters as heritability $\left(\mathrm{h}^{2} \mathrm{Gi}_{\mathrm{i}}\right)$ with confidence limits, phenotypic coefficient of variation $\left(\mathrm{CV}_{\mathrm{P}}, \%\right)$ and direct genotypic gain $\left(\Delta \mathrm{G}_{\mathrm{C}}, \%\right)$ at clonal level $(n=16)$.

\begin{tabular}{lcccccc}
\hline Method & Mean & Max & Min & $\mathrm{h}^{2}{ }_{\mathrm{Gi}}$ & $\mathrm{CV}_{\mathrm{P}}$ & $\Delta \mathrm{G}_{\mathrm{C}}$ \\
\hline $\mathrm{V}_{\mathrm{US}}\left(\mathrm{m} \mathrm{s}^{-1}\right)$ & 5000 & 5300 & 4600 & $0.61(0.20-0.85)$ & 4.5 & 3.4 \\
MOE & 10500 & 12600 & 8700 & $0.79(0.51-0.92)$ & 12.5 & 11.1 \\
$\mathrm{Fr}(\mathrm{Hz})$ & 483 & 586 & 395 & $0.35(-0.14-0.71)$ & 9.6 \\
MOE $_{\mathrm{GR}}(\mathrm{MPa})$ & 8000 & 9800 & 6300 & $0.77(0.46-0.91)$ & 5.0 \\
\hline
\end{tabular}

Table IV. Boards: mean, maximum (max) and minimum (min) of the ultrasound speed $\left(\mathrm{V}_{\mathrm{US}}, \mathrm{m} \mathrm{s}^{-1}\right.$ ) and modulus $\left(\mathrm{MOE}_{\mathrm{US}}\right.$, MPa); different genotypic parameters as heritability $\left(\mathrm{h}^{2} \mathrm{Gi}\right)$ with confidence limits, phenotypic coefficient of variation $\left(\mathrm{CV}_{\mathrm{P}}, \%\right)$ and direct genotypic gain $\left(\Delta \mathrm{G}_{\mathrm{C}}, \%\right)$ at clonal level $(n=16)$.

\begin{tabular}{lcccccc}
\hline Method & Mean & Max & Min & $\mathrm{h}^{2}{ }_{\mathrm{Gi}}$ & $\mathrm{CV}_{\mathrm{P}}$ & $\Delta \mathrm{G}_{\mathrm{C}}$ \\
\hline $\mathrm{V}_{\mathrm{US}}\left(\mathrm{m} \mathrm{s}^{-1}\right)$ & 4700 & 5100 & 4300 & $0.55(0.11-0.82)$ & 4.5 & 3.2 \\
$\mathrm{MOE}_{\mathrm{US}}(\mathrm{MPa})$ & 9500 & 11500 & 7600 & $0.74(0.42-0.90)$ & 12.5 & 10.6
\end{tabular}

nearly equal for the two alternative methods (by ultrasound speed and resonance frequency, Tab. III). They are also close to those observed on normalised specimens.

Estimates of genotypic heritability (0.61) and direct gain (3.4\%) for ultrasound speed are similar to those observed with normalised specimens (respectively 0.60 and 3.2\%). For resonance frequency, this estimate of heritability decreases from 0.64 for the normalised specimens to 0.35 for the long one but the estimate of variability increases from 5.1 to $9.6 \%$; finally, the estimated direct gain is higher for the long specimens $(5.0 \%)$.

\subsubsection{Boards}

Only the ultrasound speed was measured on each board and, in this case, modulus of elasticity $\left(\mathrm{MOE}_{\mathrm{US}}\right)$ was computed using the wood density measured on the long specimen cut from the board.

\footnotetext{
${ }^{5}$ Confidence limits according to Becker [3].
}

Table V. Logs: mean, maximum (max) and minimum (min) of the ultrasound speed $\left(\mathrm{V}_{\mathrm{US}}, \mathrm{m} \mathrm{s}^{-1}\right)$ measured in the heartwood and the sapwood; different genotypic parameters as heritability $\left(\mathrm{h}^{2} \mathrm{Gi}\right)$ with confidence limits, phenotypic coefficient of variation $\left(\mathrm{CV}_{\mathrm{P}}, \%\right)$ and direct genotypic gain $\left(\Delta \mathrm{G}_{\mathrm{C}}, \%\right)$ at clonal level $(n=16)$.

\begin{tabular}{lcccccc}
\hline Method & Mean & Max & Min & $\mathrm{h}^{2} \mathrm{Gi}$ & $\mathrm{CV}_{\mathrm{P}}$ & $\Delta \mathrm{G}_{\mathrm{C}}$ \\
\hline $\mathrm{V}_{\mathrm{US}}\left(\mathrm{m} \mathrm{s}^{-1}\right)$ & & & & & & \\
in heartwood & 4600 & 4900 & 4100 & $0.60(0.18-0.84)$ & 4.1 & 3.1 \\
in sapwood & 4600 & 4900 & 4100 & $0.55(0.11-0.82)$ & 4.5 & 3.2 \\
for the log & 4600 & 4900 & 4100 & $0.59(0.17-0.83)$ & 4.3 & 3.2 \\
\hline
\end{tabular}

Estimates of genotypic heritability and direct gain for ultrasound speed and modulus are still very high and on the level with those observed on long and normalised specimens (Tab. IV).

\subsubsection{Logs}

Measurements were realised only by the ultrasound method in sapwood and in heartwood.

Estimates of genotypic parameters (heritability and direct gain, Tab. V) are comparable to those previously observed in various $\log$ positions.

\subsubsection{Trees}

While ultrasound speed estimate of heritability seems lower compared with laboratory data $(0.37$ - Tab. VI - versus 0.55 to 0.61$)$, phenotypic variation is much higher $(13.1 \%$ versus 4.1 to $4.5 \%$ ). 
Table VI. Standing trees: mean, maximum (max) minimum (min) of the ultrasound speed $\left(\mathrm{V}_{\mathrm{US}}, \mathrm{m} \mathrm{s}^{-1}\right)$ and of the Pilodyn measures carried out in 1993 (Pil93, mm) and in 1996 (Pil96, mm); different genotypic parameters as heritability $\left(\mathrm{h}^{2} \mathrm{Gi}\right)$ with confidence limits, phenotypic coefficient of variation $\left(\mathrm{CV}_{\mathrm{P}} \%\right)$ and direct genotypic gain $\left(\Delta \mathrm{G}_{\mathrm{C}}, \%\right)$ at clonal level $\left(n=16^{6}\right)$.

\begin{tabular}{lcccccc}
\hline Method & Mean & Max & Min & $\mathrm{h}^{2}{ }_{\mathrm{Gi}}$ & $\mathrm{CV}_{\mathrm{P}}$ & $\Delta \mathrm{G}_{\mathrm{C}}$ \\
\hline $\mathrm{V}_{\mathrm{US}}\left(\mathrm{m} \mathrm{s}^{-1}\right)$ & 4900 & 5700 & 3600 & $0.37(-0.14-0.72)$ & 13.1 & 6.9 \\
Pi193 $(\mathrm{mm})$ & 18.56 & 21.75 & 16.75 & $0.62(0.21-0.85)$ & 8.9 & 6.8 \\
Pi196 (mm) & 17.83 & 20.80 & 15.40 & $0.77(0.47-0.91)$ & 8,5 & 7.4 \\
\hline
\end{tabular}

Table VII. Genotypic (above diagonal) and phenotypic (under diagonal) correlation coefficients between the moduli of elasticity estimated by the ultrasound speed $\left(\mathrm{MOE}_{\mathrm{US}}\right)$, the resonance frequency $\left(\mathrm{MOE}_{\mathrm{GR}}\right)$ and in static bending (control method $\left.-\mathrm{MOE}_{4 \mathrm{PT}}\right)^{7}$ on normalised specimens, at the clonal level $(n=16)$.

\begin{tabular}{lccc}
\hline & MOE $_{\mathrm{US}}$ & $\mathrm{MOE}_{\mathrm{GR}}$ & $\mathrm{MOE}_{4 \mathrm{PT}}$ \\
\hline MOE $_{\mathrm{US}}$ & - & 0.998 & 1.000 \\
$\mathrm{MOE}_{\mathrm{GR}}$ & $0.988 * * *$ & - & 1.000 \\
$\mathrm{MOE}_{4 \mathrm{PT}}$ & $0.985 * * *$ & $0.998 * * *$ & - \\
\hline
\end{tabular}

We also noticed that the ultrasound speed measured on standing trees and transformed by the Sandoz equation [31] is nearly equal to those measured at all stages of sawing.

Penetration depth of the striker pin in 1993 and in 1996 seems to be a more heritable characteristic, estimate of $\mathrm{h}^{2} \mathrm{Gi}$ is respectively equal to 0.62 and 0.77 and the conventional direct genotypic gains are very high (6.8 and $7.4 \%$ respectively).

\subsection{Comparison of the 3 methods}

\subsubsection{Clonal selection on normalised specimens}

With normalised specimens, even with the bias observed for the estimation of modulus of elasticity with ultrasonic speed (Fig. 1), genotypic and phenotypic correlation coefficients are very high (Tab. VII) - near or equal to 1 . Regression coefficients of the adjusted regression straight line are close to 1 , particularly with the resonance frequency method. Meanwhile, the dispersion of points around the regression straight line is more important for ultrasound speed method than for the resonance frequency method as reflected by the lowest $R^{2}$ (Fig. 1).

On a genetic standpoint, with such a strong correlation between these methods and the high estimates of heritability, direct clonal selection using the reference method as well as indirect selection with ultrasonic speed and resonance frequency methods give the same genotypic gain $(\Delta \mathrm{G}=11.5 \%)$. Thus, the reference method could be substituted by the acoustic methods for normalised specimens. This confirms the relevance of these methods for hybrid larch, which have already

\footnotetext{
6 Two missing ramets for $\mathrm{V}_{\mathrm{US}}$.

7 Symbols used for the whole document: ns: non significant; * significant for $\alpha=0.05$; ** significant for $\alpha=0.01$; *** significant for $\alpha=$ 0.001 .
}

been successfully tested and used in Norway spruce [16], fir [15], larch [22] and tropical woods [2].

\subsubsection{Clonal selection on unnormalised specimens}

As Sylvatest measurements can be carried out on wood pieces as well as on standing trees, this device was used at each preparation stage of the samples (from the living standing tree to the normalised specimen). These measurements were then compared to those from the reference method used on normalised specimens supposed to expressed the clear wood stiffness of a given clone.

\subsubsection{Logs and wood specimens}

Genotypic and phenotypic correlation coefficients calculated from ultrasound speeds measured on the different samples are very high, at least equal to 0.91 , always positive and very highly significant (Tab. VIII).

When the modulus of elasticity measured by the reference method $\left(\mathrm{MOE}_{4 \mathrm{PT}}\right)$ is compared with the ultrasound speed measured on the different samples, genotypic and phenotypic correlations decrease with the increase in the wood specimen size.

As the estimate of heritability is also lower when ultrasonic speed is measured on board or log, it results in a lower estimate of gain for clonal selection using indirect method (9\% instead of $11.5 \%$ - Tab. IX). Meanwhile, the lower estimate of gain slightly affects the final selection of the clone: in this sample (Tab. X) 4 to 5 of the first 6 clones selected with the reference method are also selected with the ultrasound speed.

\subsubsection{Standing trees}

Measurements of ultrasound speed on standing trees and penetration depth of the striker pin were taken in the basal part of the trunk. For this reason, only data from the basal log collected in laboratory are considered in this section.

For each characteristic, the mean per clone was calculated to obtain the phenotypic correlations between ultrasound speed measured on standing trees and in laboratory on the other samples (Tab. XI).

Phenotypic correlation coefficients computed between ultrasound speed measured on standing trees and the other data collected for the different kinds of samples are lowest when normalised specimen measures are concerned and are maximum with speed measured on logs. 
Table VIII. Genotypic (above diagonal) and phenotypic ${ }^{8}$ (under diagonal) correlation coefficients between the modulus of elasticity measured on normalised specimen (control method $\left.-\mathrm{MOE}_{4 \mathrm{PT}}\right)$ and the ultrasound speed $\left(\mathrm{V}_{\mathrm{US}}\right)$ measured at the different stages of the sawing, at the clonal level $(n=16)$.

\begin{tabular}{|c|c|c|c|c|c|c|c|c|}
\hline & \multirow{2}{*}{$\begin{array}{c}\mathrm{MOE}_{4 \mathrm{PT}} \\
\text { Normalised specimen }\end{array}$} & \multicolumn{6}{|c|}{$\mathrm{V}_{\mathrm{US}}$} \\
\hline & & & Normalised specimen & Long specimen & Board & Log heartwood & Log sapwood & Log mean \\
\hline \multicolumn{2}{|c|}{$\mathrm{MOE}_{4 \mathrm{PT}}$} & - & 0.95 & 0.95 & 0.87 & 0.80 & 0.83 & 0.82 \\
\hline \multirow[t]{2}{*}{$\uparrow$} & Normalised specimen & 0.98 & - & 1.00 & 0.94 & 0.99 & 0.99 & 0.99 \\
\hline & Long specimen & 0.97 & 0.99 & - & 0.96 & 0.97 & 0.99 & 0.98 \\
\hline \multirow{3}{*}{$\frac{n}{5}$} & Board & 0.90 & 0.92 & 0.94 & - & 0.93 & 0.96 & 0.94 \\
\hline & Log heartwood & 0.82 & 0.92 & 0.92 & 0.91 & - & 1.00 & 1.00 \\
\hline & Log sapwood & 0.86 & 0.93 & 0.93 & 0.94 & 0.98 & - & 1.00 \\
\hline$\downarrow$ & Log mean & 0.84 & 0.93 & 0.93 & 0.93 & 0.99 & 0.99 & - \\
\hline
\end{tabular}

Table IX. Genotypic gains for the modulus of elasticity in static bending measured on normalised specimen (control method - MOE 4 PT) by direct selection or using the ultrasound speed (Vus) measured at the different stages of the sawing, at the clonal level $(n=16)$.

\begin{tabular}{|c|c|c|c|c|c|c|c|}
\hline \multirow{2}{*}{\multicolumn{2}{|c|}{$\begin{array}{c}\text { MOE }_{4 \mathrm{PT}} \\
\text { Normalised specimen }\end{array}$}} & & \multicolumn{5}{|c|}{$\mathrm{V}_{\mathrm{US}}$} \\
\hline & & Normalised specimen & Long specimen & Board & Log heartwood & Log sapwood & Log mean \\
\hline $\mathrm{MOE}_{4 \mathrm{PT}}$ & 11.5 & 10.6 & 10.5 & 9.5 & 8.9 & 9.0 & 9.0 \\
\hline
\end{tabular}

Table X. Ranking of the 16 clones (represented by a reference number) according to the values of the modulus of elasticity in static bending measured on normalised specimen (control method $-\mathrm{MOE}_{4 \mathrm{PT}}, \mathrm{MPa}$ ) and according to the values of the ultrasound speed ( $\mathrm{V}_{\mathrm{US}}, \mathrm{m} \mathrm{s}^{-1}$ ) measured at the different stages of the sawing.

\begin{tabular}{|c|c|c|c|c|c|c|c|}
\hline \multirow[b]{2}{*}{ Clone number } & \multirow{2}{*}{$\begin{array}{c}\mathrm{MOE}_{4 \mathrm{PT}} \\
\text { Normalised specimen }\end{array}$} & \multicolumn{6}{|c|}{$\mathrm{V}_{\mathrm{US}}$} \\
\hline & & Normalised specimen & Long specimen & Board & Log heartwood & Log sapwood & Log mean \\
\hline 21 & 1 & 1 & 1 & 2 & 1 & 1 & 1 \\
\hline 19 & 2 & 2 & 2 & 1 & 6 & 5 & 7 \\
\hline 28 & 3 & 6 & 4 & 7 & 8 & 8 & 8 \\
\hline 20 & 4 & 3 & 3 & 3 & 3 & 2 & 3 \\
\hline 17 & 5 & 4 & 7 & 8 & 5 & 7 & 6 \\
\hline 12 & 6 & 5 & 5 & 4 & 4 & 6 & 4 \\
\hline 15 & 7 & 7 & 6 & 5 & $\overline{2}$ & 4 & -5 \\
\hline 29 & 8 & 8 & 8 & 6 & 7 & 3 & 5 \\
\hline 13 & 9 & 12 & 12 & 9 & 10 & 10 & 10 \\
\hline 22 & 10 & 11 & 9 & 10 & 12 & 12 & 12 \\
\hline 27 & 11 & 13 & 13 & 15 & 15 & 14 & 15 \\
\hline 18 & 12 & 10 & 10 & 12 & 9 & 9 & 9 \\
\hline 9 & 13 & 14 & 14 & 14 & 14 & 15 & 14 \\
\hline 1 & 14 & 9 & 11 & 11 & 11 & 11 & 11 \\
\hline 30 & 15 & 15 & 15 & 13 & 13 & 13 & 13 \\
\hline 5 & 16 & 16 & 16 & 16 & 16 & 16 & 16 \\
\hline
\end{tabular}

The correlation coefficient falls down to 0.51 with the reference method but stays significant.

If we look at the rankings (Tab. XII) for the basal log, we can see that 4 of the first 6 clones selected with the reference

\footnotetext{
${ }^{8}$ All the phenotypic correlation coefficients are significant for $\alpha=0.001$
}

method would also be selected with ultrasound speed on standing trees.

With the same intensity of selection, it would lead to a difference of $3.8 \%$ between the two estimates of selection gain (direct gain of $13.0 \%$ versus an indirect gain of $9.2 \%$ Tab. XIII). However it would also allow a huge gain in time and money that would permit to increase the intensity of selection and consequently the overall gain. 
Table XI. Phenotypic correlation coefficient between the ultrasound speed $\left(\mathrm{V}_{\mathrm{US}}\right)$ measured on standing trees, the modulus of elasticity in static bending measured on normalised specimen (control method $-\mathrm{MOE}_{4 \mathrm{PT}}$ ) and the ultrasound speed measured at the different stages of the sawing, at the clonal level $(n=16)$.

\begin{tabular}{|c|c|c|c|c|c|c|c|}
\hline & $\mathrm{MOE}_{4 \mathrm{PT}}$ & & & & $\mathrm{V}_{\text {US }}$ & & \\
\hline & Normalised specimen & Normalised specimen & Long specimen & Board & Log heartwood & Log sapwood & Log mean \\
\hline $\mathrm{V}_{\mathrm{US}}$ on standing trees & $0.51 *$ & $0.66 * *$ & $0.67 * *$ & $0.67 * *$ & $0.81 * * *$ & $0.81 * * *$ & $0.82 * * *$ \\
\hline
\end{tabular}

Table XII. Ranking of the 16 clones (represented by a reference number) for the basal log according to the value of the modulus of elasticity in static bending measured on normalised specimen (control method - MOE 4 PT, MPa), the ultrasound speed $\left(\mathrm{V}_{\mathrm{US}}, \mathrm{m} \mathrm{s}^{-1}\right.$ ) measured on standing trees and the penetration depth of the striker pin in 1993 (Pil93, mm) and in 1996 (Pil96, mm).

\begin{tabular}{lcccc}
\hline Clone number & Normalised specimen & \multicolumn{3}{c}{ Standing trees } \\
\cline { 2 - 5 } & MOE $_{4 \mathrm{PT}}$ & $\mathrm{V}_{\text {US }}$ & Pi193 & Pi196 \\
\hline 21 & 1 & 2 & 3 & 1 \\
19 & 2 & 9 & 2 & 3 \\
28 & 3 & 4 & 4 & 5 \\
12 & 4 & 1 & 12 & 6 \\
17 & 5 & 10 & 10 & 10 \\
15 & 6 & 3 & 9 & 11 \\
20 & $-----\frac{1}{2}---$ \\
13 & 7 & 11 & 1 & 2 \\
29 & 8 & 8 & 8 & 9 \\
22 & 9 & 7 & 16 & 15 \\
18 & 10 & 14 & 11 & 13 \\
27 & 11 & 5 & 15 & 16 \\
30 & 12 & 6 & 6 & 4 \\
9 & 13 & 11 & 14 & 12 \\
1 & 14 & 16 & 5 & 7 \\
5 & 15 & 13 & 13 & 14 \\
& 16 & 15 & 7 & 8 \\
\hline
\end{tabular}

Table XIII. Genotypic gains for the modulus of elasticity in static bending measured on normalised specimen (control method$\mathrm{MOE}_{4 \mathrm{PT}}$ ) by direct selection or using the ultrasound speed $\left(\mathrm{V}_{\mathrm{US}}\right)$ or the penetration depth of the striker pin in 1993 (Pi193) and in 1996 (Pil96) estimated on the basal log, at the clonal level $(n=16)$.

\begin{tabular}{lcccc}
\hline & $\mathrm{MOE}_{4 \mathrm{PT}}$ & $\mathrm{V}_{\mathrm{US}}$ & Pil93 & Pil96 \\
\hline $\mathrm{MOE}_{4 \mathrm{PT}}$ & 13.0 & 9.2 & -8.8 & -11.0 \\
\hline
\end{tabular}

Passing from an indirect gain of $9.2 \%$ to $13.0 \%$ would necessitate an increase of the standardized selection differential $\left(i_{\mathrm{X}}\right)$, from 1 to 1.41 . This corresponds to a selection intensity of $20 \%$ instead of $38 \%$ [28]. This can be very easily and rapidly done in the field.

Phenotypic and genotypic correlation coefficients between the Pilodyn measures and $\mathrm{MOE}_{4 \mathrm{PT}}$ (Tab. XIV) are negative. The phenotypic correlation coefficient is not significant with Pil93 ( $-0.38 \mathrm{~ns})$ and is significant with Pil96 ( $\left.-0.56^{*}\right)$.

Estimates of indirect gain on $\mathrm{MOE}_{4 \mathrm{PT}}$ by selection on Pilodyn measures (Tab. XIII) are however quite high. The estimate of indirect gain is higher for the Pilodyn measurement in 1996
Table XIV. Genotypic (above diagonal) and phenotypic (under diagonal) correlation coefficients between the penetration depth of the striker pin in 1993 (Pi193) and in 1996 (Pil96) measured on standing trees, and the modulus of elasticity in static bending measured on normalised specimen (control method $-\mathrm{MOE}_{4 \mathrm{PT}}$ ), at the clonal level $(n=16)$.

\begin{tabular}{lccc}
\hline & Pi193 & Pi196 & MOE $_{4 \mathrm{PT}}$ \\
\hline Pi193 & - & 1.00 & -0.65 \\
Pi196 & $0.87 * * *$ & - & -0.76 \\
MOE $_{4 \mathrm{PT}}$ & $-0.38 \mathrm{~ns}$ & $-0.56 *$ & - \\
\hline
\end{tabular}

(11.0\%) in comparison with the measurement in $1993(8.8 \%)$ and is also higher than the indirect gain on $\mathrm{MOE}_{4 \mathrm{PT}}$ for the basal log by selection on ultrasound speed measured on standing trees $(9.2 \%)$.

The rankings obtained with the two Pilodyn measurements are similar (Tab. XII). However, a comparison of the 3 methods shows clear differences. A group of clones (number 5, 9, 20) seems to have a low level of stiffness when the reference method and the ultrasound speed are used; conversely, with Pilodyn, these clones seem to have a higher stiffness.

The opposite is observed with clone 29 which has a very bad ranking with the 2 Pilodyn measurements and is medium with the 2 other methods.

These discordant results could be partly explained by the punctual evaluation of the Pilodyn measures and the fact that an identical density value can correspond to an important range of mechanical properties [22, 23]. It is also well known that compression wood has a higher density but a lower stiffness than normal wood [25] and, in this case, a Pilodyn measure could overestimate the stiffness if the space tested contained a part of compression wood what is possible for these larch samples.

\section{CONCLUSIONS AND PERSPECTIVES}

Compared with the normalised static bending test, used as control, the two acoustic methods of wood stiffness evaluation, the ultrasound and the resonance frequency ones, appear to be an economically profitable alternative for increasing the efficiency of clonal selection for wood stiffness.

For normalised, long specimens and also for boards, genotypic heritability of the 3 different moduli (in static bending, by ultrasound and resonance frequency) are consistently high, between 0.74 and 0.80 . As genotypic correlation coefficients between the 2 acoustic moduli and the control are also high 
(>0.9), the result is that indirect genotypic gains are as high as direct gain obtained with the control method.

When ultrasound speed is used, the estimates of genotypic gain are slightly lower $\left(9.0<\Delta \mathrm{G}_{\mathrm{Y} / \mathrm{X}}<10.6\right)$ than the control.

According to these observations, the ultrasound speed measure could be an efficient tool to carry out clonal selection whichever the sample used to estimate stiffness. Compared with the measurements taken from clear specimen, ultrasonic speed on standing tree is characterised by a lower estimate of heritability and genotypic correlation coefficient using the control method which slightly reduces the efficiency of this indirect measure. However, this loss of efficiency could be compensated by a cost reduction due to the fact that sampling steps such as felling, transportation, sawing and conditioning are avoided. This spared money could then be used to increase the intensity of selection to obtain a higher indirect gain.

If felled trees are available, ultrasonic speed measured on $\log$ offers a high indirect gain without needing additional money and time to prepare samples.

Realising the selection on standing trees with an ultrasound method has the advantage of keeping the trees alive but leads to a loss in the gain of the selection. This method also has the advantage of integrating a larger part of the trunk than an extremely punctual measure as done with a Pilodyn which does not take into account existing knots. The Rigidimeter presents the same two advantages but, in comparison with the method based on ultrasound speed, the number of trees measured per day is lower (approximately 50 trees measured per day with a Rigidimeter by a team of 3 well trained technicians [20]) and its use is limited by climatic conditions (Pâques, pers. com.) and by tree size (measurable trees should have a diameter at breast height of between 10 and $20 \mathrm{~cm} \mathrm{[20]).} \mathrm{The}$ number of trees measured per day by a team of 2 operators using the Sylvatest device approximately varies, according to the last measurement campaign, from 80 to 100 (2 ultrasound speed measurements per tree).

Taking into account the time needed to measure with the different devices, a two-step selection seems to be an interesting solution in the frame of hybrid larch clonal selection: a first rapid evaluation using Pilodyn could be realised and then, based on these results, the Sylvatest or Rigidimeter could be used on a small number of preselected clones.

On normalised specimens, the control method can also be substituted by the resonance frequency method which has the advantage of providing, in average, the same modulus that the modulus of elasticity in static bending $(8000 \mathrm{MPa})$ with very near minima and maxima (respectively 6300 versus 6500 and 9800 versus $9700 \mathrm{MPa}$ ). This is not the case of the ultrasound method which overestimates the average modulus by $25 \%$ $(10000 \mathrm{MPa})$.

Acknowledgments: The authors gratefully thank the CRNFB technical team (Roger Buchet, Alain Lemaire, Thierry Porphyre and Michel Thielens) for their assistance in preparation and assessment of wood samples. The authors also thank Aline Brion and the anonymous reviewers for their interesting and relevant comments.

\section{REFERENCES}

[1] Anonymous, French Norm NF-B 51-016, Bois, Essais de flexion statique, détermination du module d'élasticité en flexion statique de petites éprouvettes sans défauts, 1987, 6 p.

[2] Baillères H., Demay L., Calchéra G., Vernay M., Classement mécanique des bois guyanais de structure selon trois techniques non destructives, Bois et forêts des tropiques 257 (1998) 47-61.

[3] Becker W.A., Manual of quantitative genetics, Academic Entreprises, Washington, 1985, 190 p.

[4] Bucur V., Détermination du module d'Young du bois par une méthode dynamique sur carottes de sondage, Ann. Sci. For. 38 (1981) 283-298.

[5] Bucur V., Archer R.R., Elastic constants for wood by an ultrasonic method, Wood Sci. Technol. 18 (1984) 255-265.

[6] Chatre M., Gourlaouen J.C., Poirson G., Application de la détermination de la fréquence de résonance au contrôle des produits réfractaires, Conférence présentée au congrès de contrôle nondestructif à Mayence, avril 1978

[7] Chantre G., Sutter-Barrot E., Gouma R., Bouvet A., De l'intérêt de l'utilisation du Pilodyn dans l'étude de la qualité du bois, Annales AFOCEL, 1992, pp. 145-177.

[8] Costa E Silva J., Nielsen U.B., Roulund H., Sitka spruce clonal performance with special reference to basic density, Silvae Genet. 43 (1994) 82-91.

[9] Costa E Silva J., Borralho N.M.G., Wellendorf H., Genetic parameter estimates for diameter growth, Pilodyn penetration and spiral grain in Picea abies (L.) Karst., Silvae Genet. 49 (2000) 29-36.

[10] Cown D.J., Comparison of the Pilodyn and torsiometer methods for the rapid assessment of wood density in living trees, N. Z. J. For. Sci. 8 (1978) 384-391.

[11] Croiset G., Leclercq A., Lecomte H., Questienne P., Étude comparative de deux méthodes de détermination du module d'élasticité du bois et de ses dérivés, Station de technologie forestière, CRA, Gembloux, rapport interne, 1980, 52 p.

[12] Dagnelie P., Statistique théorique et appliquée. Tome 2. Inférence statistique à une et à deux dimensions, De Boeck Université, 1998, $659 \mathrm{p}$.

[13] Dzbenski W., Versuche zur Anwendung der UltraschallMesstechnik bei der Gütesortierung von Konstruktionsholz nach seiner Festigkeit, Holzforschung und Holzverwertung 33 (1981) $105-110$.

[14] Jacques D., Nanson A., Vers l'utilisation des variétés multiclonales en Région wallonne? Silva Belgica 105 (1996) 22-26.

[15] Haines W., Leban J.-M., Herbé C., Determination of Young's modulus of elasticity for spruce, fir and isotropic materials by the resonance flexure method with comparisons to static flexure and other dynamic methods, Wood Sci. Technol. 30 (1996) 253-263.

[16] Haines W., Leban J.-M., Evaluation of the MOE of Norway spruce by the resonance flexure method, For. Prod. J. 47 (1997) 91-93.

[17] Koizumi A., Ueda K., Estimation of mechanical properties of standing trees by bending tests III, Modulus of elasticity of tree trunks of plantation-grown conifers, Mokuzai Gakkaishi 33 (1987) $450-456$.

[18] Koizumi A., Takata K., Ueda K., Katayose T., Radial growth and wood quality of plus trees of Japanese larch. I. Radial growth, density, and trunk modulus of elasticity of grafted clones, Mokuzai Gakkaishi 36 (1990) 98-102.

[19] Koizumi A., Takata K., Ueda K., Radial growth and wood quality of plus trees of Japanese larch. II. Diameters at breast heights and 
trunk moduli of elasticity of 18-years-old offspring families, Mokuzai Gakkaishi 36 (1990) 704-708.

[20] Launay J., Rozenberg P., Pâques L., Dewitte J.M., A new experimental device for rapid measurement of the trunk equivalent modulus of elasticity on standing trees, Ann. For. Sci. 57 (2000) 351-359.

[21] Launay J., Ivkovich M., Pâques L., Bastien C., Higelin P., Rozenberg P., Rapid measurement of trunk MOE on standing trees using RIGIDIMETER, Ann. For. Sci. 59 (2002) 465-469.

[22] Leban J.M., Haines W., The modulus of elasticity of hybrid larch predicted by density, rings per centimeter and age, Wood Fiber Sci. 31 (1999) 394-402.

[23] Leclercq A., Relationships between beechwood anatomy and its physico-mechanical properties, IAWA Bulletin 1 (1980) 65-75.

[24] Lemmens J.X., Operating instructions for Grindo-Sonic MK3 equipment, Note technique, date non communiquée, 23 p.

[25] Low A.J., Compression wood in conifers, A review of literature, Forestry Abstracts 25 (1964) 35-43.

[26] Mamdy C., Rozenberg P., Franc A., Launay J., Schermann N., Bastien J.C., Genetic control of stiffness of standing Douglas fir; from the standing stem to the standardised wood sample, relationships between modulus of elasticity and wood density parameters, Part I, Ann. For. Sci. 56 (1999) 133-143.

[27] Marchal M., Jacques D., Évaluation de deux méthodes acoustiques de détermination du module d'élasticité de bois de mélèze hybride jeune (Larix x eurolepis Henry) - comparaison avec une méthode normalisée en flexion statique, Ann. For. Sci. 56 (1999) 333-343.

[28] Nanson A., Tables de la différentielle de sélection dans la distribution normale $(0,1)$, Biom. Praxim. 8 (1967) 40-517.

[29] Nanson A., L'héritabilité génotypique et le gain d'origine génétique dans quelques types d'expériences, Silvae Genet. 19 (1970) 113-121.

[30] Nanson A., Genotypic and genetic parameters, early testing and genotype $\times$ environment interaction, Proc. IUFRO Meet. S2.02.11, Tjörnarp, Sweden, Sept. 88, 1988, 16 p.

[31] Sandoz J.L., Moisture content and temperature effect on ultrasound timber grading, Wood Sci. Technol. 27 (1993) 373-380.

[32] Spinner S., Tefft W.E., A method for determining mechanical resonance frequencies and for calculating elastic moduli from these frequencies, in: Proceedings ASTM, Vol. 61, 1961, pp. 1221-1238.

[33] Vafai A., Farshad M., Modulus of elasticity of wood in standing trees, Wood Sci. 12 (1979) 93-97. 